Lovell AM, Carr JR, Stokes CR. Topographic controls on the surging behaviour of Sabche Glacier, Nepal (1967 to 2017). Remote Sensing of

Environment 2018, 210, 434-443.

DOI link

https://doi.org/10.1016/j.rse.2018.03.036

ePrints link

http://eprint.ncl.ac.uk/247195

Date deposited

$04 / 04 / 2018$

Embargo release date

03/04/2019

Copyright

(C) 2018. This manuscript version is made available under the CC-BY-NC-ND 4.0 license

\title{
Licence
}

This work is licensed under a

Creative Commons Attribution-NonCommercial-NoDerivatives 4.0 International licence

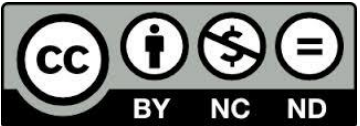




\section{Topographic controls on the surging behaviour of Sabche Glacier, Nepal}

2

3

4

5

6

7

8

9

10

11

(1967 to 2017)

Arminel M. Lovell ${ }^{\mathbf{a} *}$, J. Rachel Carr ${ }^{\mathbf{a}}$ and Chris R. Stokes ${ }^{\mathbf{b}}$

a School of Geography, Politics and Sociology, Newcastle University, $5^{\text {th }}$ Floor Claremont

Tower, Newcastle upon Tyne, NE1 7RU, UK

${ }^{\text {b}}$ Department of Geography, Durham University, South Rd, Durham, DH1 3LE, UK

*Corresponding author: a.m.lovell2@newcastle.ac.uk

Keywords: Surge; Central Himalayas; Topographic controls; Feature tracking; DEM; Landsat; Pléiades; CORONA

(C) 2018. This manuscript version is made available under the CC-BY-NC-ND 4.0 license http://creativecommons.org/licenses/by-nc-nd/4.0/.

Access the published journal article at: https://doi.org/10.1016/j.rse.2018.03.036.

\section{Abstract}

Using a combination of Landsat, Pléiades and CORONA satellite imagery from 1967 to 2017, we map changes in the terminus position, ice surface velocity and surface elevation of Sabche Glacier, and report the first observations of surging behaviour in central Nepal. Our observations show that Sabche Glacier surged four times over the last 50 years. The three most recent surges occurred at 10 to 11 -year cycles, which is one of the shortest surge cycles ever recorded. Detailed analysis of the most recent surge (2012 onwards), indicates that the glacier advanced $2.2 \mathrm{~km}$ and experienced maximum velocities of $1.6 \pm 0.10 \mathrm{~m} \mathrm{day}^{-1}$. During this surge, there was a surface elevation gain at the terminus of up to $90 \pm 6.19 \mathrm{~m} \mathrm{a}^{-1}$, with a corresponding 
surface lowering of between $10 \pm 6.19$ and $60 \pm 6.19 \mathrm{~m} \mathrm{a}^{-1}, 3 \mathrm{~km}$ up-glacier of the terminus. This transfer of mass amounted to a volume of $\sim 2.7 \times 10^{7} \pm 0.1 \times 10^{7} \mathrm{~m}^{3} \mathrm{a}^{-1}$. Sabche Glacier is the first surge-type glacier to be observed in the central Himalayas, but this is consistent with a previous global analysis which indicates that surge-type glaciers should exist in the region. We hypothesise that the surge is at least partially controlled by subglacial topography, whereby a major subglacial overdeepening and constriction $3 \mathrm{~km}$ up-glacier of the terminus provides resistance to glacier flow from the accumulation area to the ablation area. This overdeepening appears to store mass until a threshold is crossed, after which the glacier flows out of the subglacial depression and rapidly surges over a bedrock lip and down the valley. Thus, whilst the surges are likely to be facilitated by subglacial processes (e.g. changes in subglacial hydrology and/or basal thermal regime), the topographic setting of the glacier appears to be modulating both the timing and duration of each surge.

\section{Introduction}

Surge-type glaciers fluctuate between long periods (10s to 100s of years) of slow flow and shorter periods (1 to 10 years) of faster flow, during which ice surface velocities increase by up to three orders of magnitude (e.g. Clarke et al. 1984; Jiskoot et al. 1998; Meier and Post 1969). These oscillations are not thought to be directly triggered by external climate forcing, but rather by internal instabilities, linked to changing conditions at the glacier bed (Meier and Post 1969; Sevestre and Benn 2015; Sharp 1988). During the slow, or quiescent, phase of the surge cycle, ice builds up in a reservoir area, and is then transferred rapidly down-glacier to a receiving area, during the fast, or surge, phase (e.g. Meier and Post 1969; Murray et al. 2000). There is a distinct pattern in the global distribution of surge-type glaciers, with large clusters found in Alaska-Yukon, Arctic Canada, Greenland, Iceland, Svalbard, and High Mountain 
47 Asia, while very few have been recorded in other regions such as the European Alps or Scandinavia (Jiskoot et al. 1998; Sevestre and Benn 2015; Sharp 1988). While the lengths of the surge and quiescent phases tend to be consistent for individual surge-type glaciers, marked differences have been observed between these different geographic regions (e.g. Meier and Post 1969; Murray et al. 2003; Sevestre and Benn 2015). Glaciers in Svalbard tend to have surge periods lasting between 3 and 10 years and quiescent periods lasting between 50 and 500 years (Dowdeswell et al. 1991). In contrast, surge-type glaciers in Alaska-Yukon, the Pamirs, and Iceland, have much shorter surge (1 to 3 years) and quiescent (20 to 40 years) phases (Dowdeswell et al. 1991; Murray et al. 2003). These observed differences have led to the development of two main theories to explain surge-type glacier behaviour through either a thermal (Clarke et al. 1984; Murray et al. 2003) or hydrological (Kamb 1987) mechanism. Thermally-driven glacier surges, common in Svalbard, are thought to be triggered by changes in the basal thermal regime, whereby a surge-front of warm-based and fast-flowing ice propagates down-glacier into stagnant cold-based ice and activates it into surging (Clarke et al. 1984; Murray et al. 1998). Thermal glacier surges can also be influenced by changes in the amount of bed deformation occurring under the glacier (Clarke et al. 1984; Jiskoot et al. 1998). In contrast to thermally-driven surges, temperate glaciers, such as Variegated Glacier (Kamb et al. 1985) and West Fork Glacier (Harrison et al. 1994) in Alaska, are thought to surge due to changes in their basal hydrology. Specifically, surging occurs when an efficient subglacial hydrological system switches to an inefficient cavity system generating increased water pressures at the bed and promoting rapid basal sliding (Kamb 1987).

While surge-type glaciers are rare, constituting less than $1 \%$ of glaciers worldwide (Jiskoot et al. 1998), they can provide valuable insight into glacier dynamics and the mechanisms triggering surge-type behaviour and fast glacier flow (Clarke 1987). They can also present major hazards in populated areas through their influence on glacial lake outburst floods 
(GLOFs), rapid meltwater and sediment release, and the overriding of infrastructure (Haeberli et al. 2002; Kääb et al. 2005; Richardson and Reynolds 2000). Moreover, knowledge of the spatial distribution of surge-type glaciers is vital for separating internal glacier dynamics from the climate change signal. This is especially important in High Mountain Asia, as the spatial distribution of surge-type glaciers in the region is highly variable (Sevestre and Benn 2015) and the region is undergoing accelerated glacier changes due to climatic forcing (Gardelle et al. 2012; Gardelle et al. 2013; Kääb et al. 2012).

Surge-type glaciers in High Mountain Asia have been well-documented in the Karakoram (Copland et al. 2009; Copland et al. 2011; Gardner and Hewitt 1990; Hewitt 2007; Quincey et al. 2011), Pamirs (Dolgoushin and Osipova 1975; Kotlyakov et al. 2008) and Tien Shan (Dolgoushin and Osipova 1975; Pieczonka and Bolch 2015). However, no glacier surges have been recorded in the central Himalayas, which we define as the section of the Himalayan range extending from Northern India to Bhutan (Fig. 1). Despite this, Sevestre and Benn (2015) predicted that surge-type glaciers should occur in this region using the species distribution model Maxent. The model used climatic (mean annual temperature (MAT) and mean annual precipitation (MAP)) and geometric (glacier length and slope) data to predict the global distribution of surge-type glaciers. This is based on the compilation of a geodatabase of known surge-type glaciers which revealed that they preferentially cluster within a distinct climatic envelope (with an MAT range of -12 to $+8^{\circ} \mathrm{C}$ and an MAP range of 165 to $2155 \mathrm{~mm} \mathrm{a}^{-1}$ ) and that they tend to be longer and have shallower mean surface slopes than normal glaciers in these regions (Sevestre and Benn 2015). In High Mountain Asia, the model accurately predicted the likelihood of surge-type glaciers in the Pamirs, Karakoram and Tien Shan. It also predicted surge-type glaciers in the central Himalayas, but they noted the absence of observations of surging in this region and speculated that the model might be over-predicting their occurrence (Sevestre and Benn 2015). 

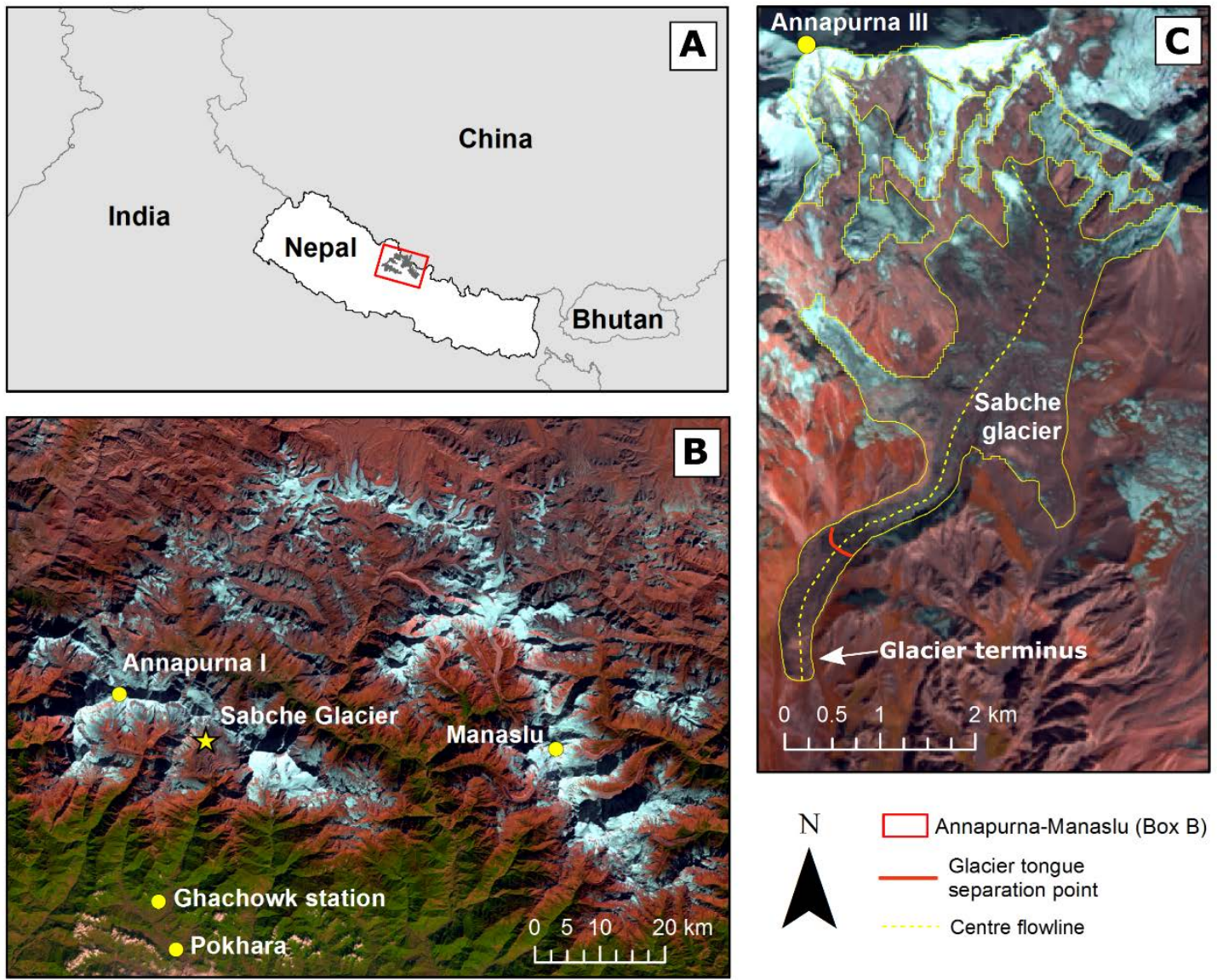

Figure 1: Study area map. A) Location of the central Himalayas and the A-M region in Nepal, B) location of Sabche Glacier in the A-M region, Pokhara and Ghachowk hydrological station and C) map of Sabche Glacier with the central flowline (yellow dotted line), the approximate position of the recurring separation point between the main body of the glacier and its tongue (red line) and the location of Annapurna III. The white arrow indicates the location of the glacier terminus. The base image is a pan-sharpened Landsat 8 scene from $1^{\text {st }}$ December 2015, courtesy of USGS.

In this paper, we use observations of frontal position, ice surface velocity and surface elevation change to identify a surge-type glacier in the large (10 km wide) Sabche cirque basin in the Annapurna-Manaslu (A-M) region in central Nepal, hereafter referred to as Sabche Glacier. This represents the first surge-type glacier to be recorded in the central Himalayas. We compare its characteristics to surge-type glaciers elsewhere in High Mountain Asia and other geographic regions, and discuss the possible mechanisms controlling its behaviour. 
Sabche Glacier $\left(28.56^{\circ} \mathrm{N}, 84.01^{\circ} \mathrm{E}\right.$ ) (Fig. 1) is in the south-west of the A-M region, on the south-east facing slope of Annapurna III (location in Fig. 1C). It is one of the larger glaciers in the A-M region with an area of $9.1 \mathrm{~km}^{2}$ in 2014 . It has a mean surface slope of $28.2^{\circ}$, a mean aspect of $178^{\circ}$ and descends across a large altitudinal range, from 7489 to $3773 \mathrm{~m}$ asl, based on a glacier outline we digitised from a Landsat 8 scene from $1^{\text {st }}$ December 2015 (Table S1).

Over half of the glacier's area $\left(5.2 \mathrm{~km}^{2}, 57 \%\right)$ is covered in supraglacial debris and it sits in the steep-sided, bowl-shaped Sabche basin, and flows into a narrow outlet, forming a long (3 km) glacier tongue (Fig. 1C).

Sabche Glacier is located at the head of, and feeds into, the Seti Gandaki river, which flows through highly populated areas, including Pokhara (population 4400,000 ), located $30 \mathrm{~km}$ down-stream. The Seti Gandaki river has a history of dramatic, and occasionally deadly, flooding events (Fort 1987; Oi et al. 2014). Between 1000 and 500 years ago, catastrophic debris-flows led to the formation of the large sediment-filled basin upon which Pokhara is located (Yamanaka 1982). Sedimentological studies indicate that the majority of clasts (90\%) deposited by these events were provided by perched glacial tills in the large Sabche cirque, originally derived from the glaciated cirque headwall (Fort 1987). While it has been suggested that the debris-flows were triggered by a series of earthquakes between A.D. 1100 and 1344 (Schwanghart et al. 2015), the mechanisms capable of transporting sufficiently large volumes of debris down-valley are still open to debate, with GLOFs and rock-ice avalanches proposed as potential agents (Fort 1987; Schwanghart et al. 2015). More recently, in May 2012, hyperconcentrated floods in the Seti Gandaki killed 13 people, triggered by a massive rock and ice avalanche from Annapurna IV (Evans and Delaney 2015; Oi et al. 2014; Schwanghart et al. 2015). 
135 The impact of Sabche Glacier's behaviour on river outputs and the related flooding events has 136 not been assessed. However, surge-related outburst floods have been observed in other regions, 137 including: i) Skeiðarárjökull in Iceland where, in 1991, a glacier surge led to the partial 138 drainage of the subglacial lake Grímsvötn (Björnsson 1998); ii) Bering Glacier in Alaska, 139 where an outburst flood coincided with the termination of the first of a two-stage surge between 1401993 and 1995 (Burke et al. 2010; Fleisher et al. 1998); and iii) Medvezhiy Glacier, in the 141 Pamirs (Dolgoushin and Osipova 1975). Based on the severity of previous floods in the Seti 142 Gandaki, the potential contribution of Sabche Glacier to major flooding events warrants further 143 investigation. 


\subsection{Data acquisition}

Landsat satellite images were obtained at annual to sub-annual intervals from 1988 to 2017

147 (Landsat 5 to 8) from the US Geological Survey (USGS: https://earthexplorer.usgs.gov/)

148 (details of individual scenes are summarised in Table S1). The spatial resolution of the Landsat scenes varied from 15 to 30 m (Table S1). Where possible, scenes were chosen between

October and February of each year to minimise the likelihood of cloud and snow cover associated with the Asian monsoon (see Table S1 for exact dates). There were no discernible seasonal differences in terminus position $(<15 \mathrm{~m})$ between October and February during the quiescent phases. CORONA satellite imagery from the $\mathrm{KH}-4 \mathrm{~A}, \mathrm{KH}-4 \mathrm{~B}$ and $\mathrm{KH}-9$ satellite missions were obtained from the USGS for the years 1967, 1970 and 1974, with spatial resolutions ranging from 2 to $6 \mathrm{~m}$ (Table S1). These dates were dictated by the availability of cloud-free imagery. In order to minimise topographic distortion, a subset image of each CORONA scene was created to cover the glacier terminus area and these were then georeferenced to a Landsat 8 base image (LC81420402015335LGN00) (Table S1) by matching easily recognisable, stable features around the terminus in the two scenes using tie-points. This yielded root mean square (RMS) values between 11 and $20 \mathrm{~m}$, which is comparable to the pixel resolution. The co-registration error for the CORONA imagery was calculated by measuring the displacement between 15 points on known stable ground between the CORONA images and the Landsat base image. Mean co-registration error was $35 \mathrm{~m}$ for the 1967 scene, $36 \mathrm{~m}$ for the 1970 scene and $24 \mathrm{~m}$ for the 1974 scene. These errors are much smaller than the observed terminus changes. Two pairs of Pléiades satellite panchromatic stereo scenes, from $12^{\text {th }}$ October 2014 and $19^{\text {th }}$ November 2015, were also obtained from the European Space Agency (ESA) (Table S1). The scenes were chosen to capture the before- and after-surge configuration of the glacier and for their minimal snow and cloud cover. These scenes had a spatial resolution 
of $0.5 \mathrm{~m}$. The 2014 stereo pair had along-track angles of $-9.6^{\circ}$ and $4.8^{\circ}$ (convergence angle of $14.4^{\circ}$ ) and the 2015 pair had along-track angles of $-8^{\circ}$ and $3.4^{\circ}$ (convergence angle of $11.4^{\circ}$ ).

\subsection{Glacier terminus position change}

Glacier terminus positions were digitised manually from CORONA scenes in 1967, 1970 and 1974 and from Landsat scenes between 1988 and 2017 at roughly annual intervals, and subannually (1- to 6-month intervals) where cloud-free images were available (Table S1). Glacier terminus position change was calculated using the well-established box method (e.g. Moon and Joughin 2008), using a curvilinear box to account for a bend in the valley (Lea et al. 2014). The rate of terminus position change was calculated in both $\mathrm{m} \mathrm{day}^{-1}$ and $\mathrm{m} \mathrm{a}^{-1}$ to allow comparisons with other studies. Manual digitising was conducted by the same person to maximise consistency in the method and interpretation of the glacier terminus position. The digitising error for the glacier terminus position changes was assessed by repeatedly digitising the terminus and measuring the maximum variation between the digitised lines from a representative scene per satellite data type. Digitising errors ranged from 11 to $26 \mathrm{~m}$.

\subsection{Glacier velocities}

East/west and north/south surface displacements were mapped using feature tracking in COSICorr software (Leprince et al. 2007) on four pairs of band 8 panchromatic scenes from the Landsat 7 ETM+ and Landsat 8 OLI TIRS sensors (15 m resolution) taken between 2011 and 2016. The intervals between the images in each pair used to calculate the velocity measurements depended on image availability. Some scenes were affected by cloud or snow cover and therefore could not be used. Consequently, intervals between scenes ranged from 16 to 48 days. Glacier velocities were not calculated for the period prior to 2011 due to the lack 
of suitable imagery. Before calculating velocity, the displacement maps were post-processed using tools in COSI-Corr to filter out noise with a signal-to-noise ratio of less than 0.9, following methods by Scherler et al. (2008) (Fig. S1). The correlations derived from the Landsat 7 scenes required additional filtering to remove striping introduced by attitude effects in the satellite imagery (Scherler et al. 2008) (Fig. S2). Shadow, cloud, and areas affected by snowfall, especially where snow was present in one scene of the pair and not the other, tended to generate noise in the velocity output and were masked out and a simple directional filter was applied to remove erroneous displacement values that clearly contradicted the direction of general glacier flow (Fig. S1). Daily velocities $\left(\mathrm{m} \mathrm{day}^{-1}\right)$ were calculated by dividing the velocity maps by the number of days in each interval. Error was estimated for each map by calculating the mean of the velocity values extracted from 30 points located off-glacier around Sabche Glacier (location of points in Fig. S3). The same points were used for each velocity map and they were placed on terrain that was judged to be stable (e.g. vegetated or with shallow slopes where possible). Errors for individual velocity maps ranged from $\pm 0.06 \mathrm{~m}^{-1 a y}{ }^{-1}$ to \pm $0.12 \mathrm{~m} \mathrm{day}^{-1}$ (Fig. S3). The glacier outline, separating on- and off-glacier areas was manually digitised from Landsat imagery.

\subsection{Digital elevation models and changes in glacier surface elevation and volume}

Digital elevation models (DEMs) of Sabche Glacier were generated from the $12^{\text {th }}$ October 2014 and $19^{\text {th }}$ November 2015 Pléiades stereo pairs using Erdas Imagine’s Photogrammetry Suite. The Pléiades scenes, which were obtained at primary processing level, were georeferenced using just the rational polynomial coefficients (RPCs) provided with each scene because we did not have any ground control points (GCPs) for the area. Over 100 tie-points were used on each stereo pair to minimise the root mean squared error (RMSE) of the triangulation models. 
Both stereo pairs had RMSE values of 0.07 pixels. Following Berthier et al. (2014), we chose an output spatial resolution of $4 \mathrm{~m}$ for the DEMs to decrease processing time but maintain sufficient detail for analysis. Due to the lack of accurate GCPs on Sabche Glacier, it was only possible to generate relative DEMs using tie-points rather than absolute DEMs. However, a previous assessment of the quality of a pair of absolute DEMs generated with GCPs and a pair of relative DEMs generated without GCPs, revealed that the mean off-glacier elevation differences between the absolute and relative pairs were very similar (within $0.03 \mathrm{~m}$ ) once both pairs had been horizontally and vertically co-registered using the stable (off-glacier) terrain (Berthier et al. 2014).

The Pléiades DEMs were assessed and corrected following Nuth and Kääb (2011) (Fig. S4). First, areas in the DEMs affected by noise due to cloud cover and shadow were filtered out. Next, the DEMs were horizontally and vertically co-registered by iteratively minimising the root mean square height difference of stable (off-glacier) terrain (Nuth and Kääb 2011) (Fig. S4A and B). It was calculated that the 2014 Pléiades DEM needed to be shifted 45.34 m, -18.47 $\mathrm{m}$ and $-201.25 \mathrm{~m}$ in the $\mathrm{x}, \mathrm{y}$ and $\mathrm{z}$ direction, respectively, to align the DEMs. Following this, the DEMs were assessed for an elevation-dependent bias by plotting elevation differences against elevation on stable terrain only (Nuth and Kääb 2011). However, no obvious bias was observed and, as such, no correction was undertaken (Fig. S4F). Due to the lack of GCPs and other high resolution DEMs of the area, it was not possible to validate the quality of the DEMs against an independent dataset. However, the relative error between the DEMs was assessed using the mean, median and standard deviation of the differences between the two datasets on stable terrain (see Nuth and Kääb 2011) (Table 1). The normalised median absolute deviation (NMAD) was used as an additional assessment of vertical precision between the datasets which is less sensitive to outliers compared with the standard deviation (see Berthier et al. 2014) 
241 (Table 1). Error in the text is quoted as the standard deviation $\left(\mathrm{m} \mathrm{a}^{-1}\right)$ of elevation differences on stable terrain (Nuth and Kääb 2011).

246

Table 1: Statistics of the off-glacier elevation differences between the two DEMs (mean, median, standard deviation and NMAD), calculated for 4 900000 pixels, before and after co-registration and converted to $\mathrm{m} \mathrm{a}^{-1}$.

\begin{tabular}{lccc}
\hline & $\begin{array}{c}\text { DEM before } \\
\text { co-registration }\end{array}$ & $\begin{array}{c}\text { DEM after co- } \\
\text { registration }\end{array}$ & $\begin{array}{c}\text { DEM after co- } \\
\text { registration }\left(\mathbf{m ~ a}^{-\mathbf{1}}\right)\end{array}$ \\
\hline Mean (m) & -206.01 & -0.42 & -0.37 \\
\hline Median (m) & -208 & -0.6 & -0.54 \\
\hline $\begin{array}{l}\text { Standard } \\
\text { deviation (m) }\end{array}$ & 36.85 & 6.83 & 6.19 \\
\hline NMAD (m) & 27.43 & 1.99 & 1.81 \\
\hline
\end{tabular}

The large horizontal and vertical shifts required to co-register the DEMs were most likely a result of the tools we used to process the DEMs. Much smaller shifts can be obtained using alternative tools (E. Berthier, personal communication, 2018), but this does not affect the relative differences in elevation that we report in this paper. The DEM corrections, following established correction procedure by Nuth and Kääb (2011), reduced the standard deviation of elevation differences on stable terrain from $36.85 \mathrm{~m}$ to $6.83 \mathrm{~m}\left(6.19 \mathrm{~m} \mathrm{a}^{-1}\right)$ and the mean elevation difference from -206.01 to $\left.-0.42 \mathrm{~m} \mathrm{(-0.37} \mathrm{m} \mathrm{a}^{-1}\right)$ (Table 1 and Fig. S4D and E). This error is much smaller than the on-glacier surface elevation changes we expect to observe and is consistent with the error values of corrected DEMs in other studies (King et al. 2017; Nuth and Kääb 2011). We are therefore confident that DEM co-registration has reduced geolocation errors sufficiently to obtain useful surface elevation change data. Figure S4D and E show summaries of elevation differences on the stable terrain before correction and after correction. Glacier surface elevation change was calculated by subtracting the 2014 DEM from the 2015 DEM and was converted into annual elevation change for comparison with other studies. Only relative, rather than absolute, surface elevation change was calculated, due to the lack of GCPs. However, this is sufficient for our analysis which aims to assess how Sabche Glacier's surface 
263 elevation on $19^{\text {th }}$ November 2015 has changed relative to $12^{\text {th }}$ October 2014 . Mean glacier

264 elevation changes per 200 m elevation band were calculated for the lower and intermediate

265 elevations on the glacier (3600-4800 m elevation). Mean elevation changes were not calculated

266 for the upper elevation bands due to large gaps in the data.

267 Surface elevation change was converted into volume change for the area of maximum elevation

268 loss and the area of maximum elevation gain (locations in Fig. S5) by multiplying the on-

269 glacier elevation differences by the area of the glacier sub-sections. We did not calculate

270 volume change for the upper glacier area due to a large number of data gaps. The upper and

271 lower error boundaries of volume change were calculated by adding/subtracting the mean off-

272 glacier error from the mean elevation change of each glacier sub-section and multiplying by its

273 area.

274 Glacier geometry including area, centre flowline length, hypsometry, altitudinal range and 275 aspect were calculated for Sabche Glacier using Landsat imagery and the ASTER GDEM v2. 


\subsection{Glacier frontal position change (1967 to 2017)}

284

Terminus position measurements show that Sabche Glacier advanced four times between 1967 and 2017 (Fig. 2). There was an interval of at least 17 years between the first period of advance (measured in 1974) and the beginning of the second period of advance (1991) and the last three advance periods occurred at 10 to 11-year intervals (Fig. 2). However, we may have missed an additional advance due to the data gap between 1974 and 1988, given the interval between the three most recent advances. The maximum distance of terminus advance varied between the first three surges (Fig. 2). During both the second and third advance periods, the terminus had an initially rapid advance $\left(\sim 1 \mathrm{~m} \mathrm{day}^{-1}, \sim 365 \mathrm{~m} \mathrm{a}^{-1}\right)$ lasting several months, reducing into a less rapid advance $\left(<0.5 \mathrm{~m} \mathrm{day}^{-1},<180 \mathrm{~m} \mathrm{a}^{-1}\right)$ and followed by retreat. The most recent advance period, from 2012 onwards, was of a much greater magnitude and more rapid than the previous three, with a maximum advance rate of $5.2 \mathrm{~m} \mathrm{day}^{-1}\left(1900 \mathrm{~m} \mathrm{a}^{-1}\right)$ between May and November 2015 and a maximum advance of $2.2 \mathrm{~km}$, relative to 1967, at the most recent measurement date (25 ${ }^{\text {th }}$ March 2017) (Fig. 2). This advance also slowed down towards the end of the measurement period ( 0.5 $\mathrm{m}_{\text {day }}{ }^{-1}, ~ 180 \mathrm{~m} \mathrm{a}^{-1}$ between January and March 2017). High magnitude and rapid retreats in terminus position followed the first three periods of advance in 1974 (-1.5 km), 1995 $(-1 \mathrm{~km})$ and $2008(-0.8 \mathrm{~km})$ (Fig. 2). These retreat events occurred where the glacier tongue disconnected from the main glacier body as a result of localised acceleration and glacier extension caused by a large increase in slope (Fig. 1C and 3 and Fig. 5D). An animated timelapse video of Landsat imagery showing the three most recent periods of advance (1988-2015) can be viewed in Supplementary video. 


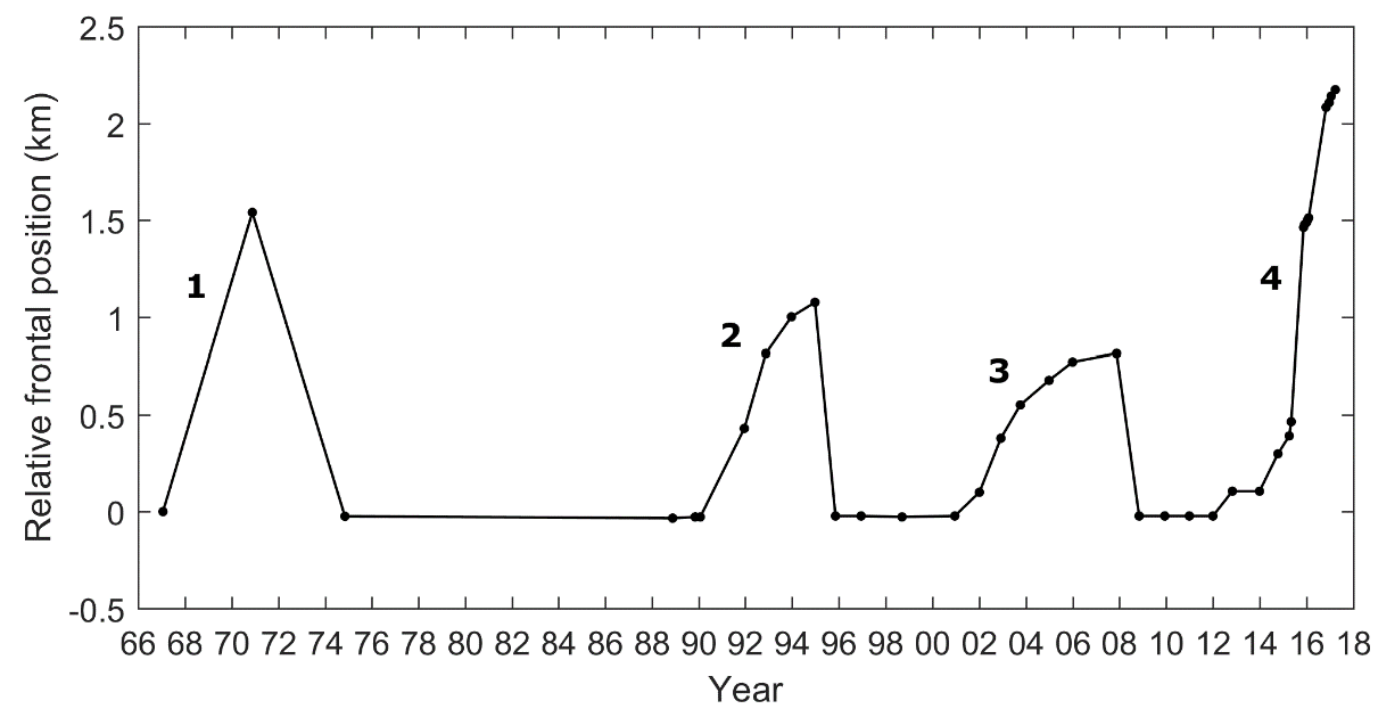

Figure 2: Glacier frontal position changes of Sabche Glacier relative to 1967 with individual advance (surge) periods numbered (1 to 4). Circles plot measurement dates.
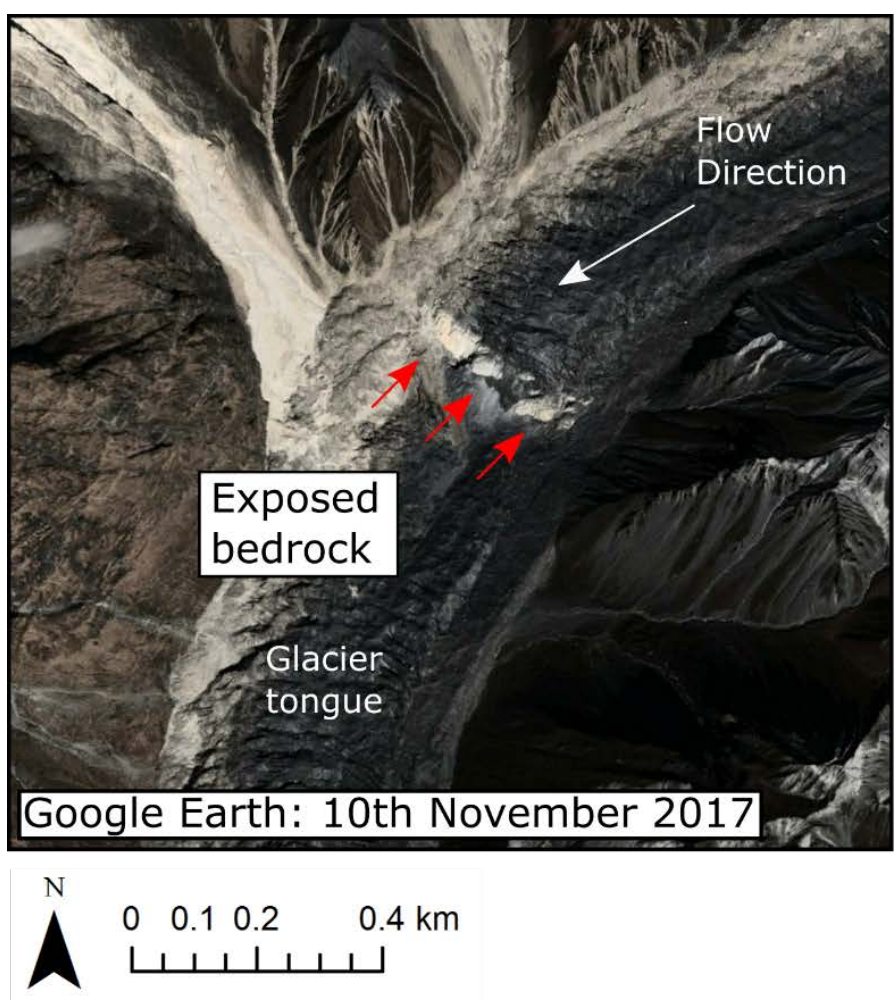

Figure 3: A large increase in slope encouraging localised acceleration and extension, leading to the separation of Sabche Glacier's tongue from the main part of the glacier and the exposure of bedrock in November 2017. See Figure 1 for the position of the recurring separation point on Sabche Glacier. Background image: Digital Globe imagery on Google Earth on 10 ${ }^{\text {th }}$ November 2017. 
316 Ice surface velocities were calculated between 2011 and 2016, covering the most recent

317 advance period. In November and December 2011, before the most recent terminus advance, 318 glacier tongue velocities ranged from 0 to $0.8 \pm 0.08 \mathrm{~m} \mathrm{day}^{-1}\left(\sim 290 \mathrm{~m} \mathrm{a}^{-1}\right)$ and there were 319 minimal changes in terminus position (Fig. 4B). By December 2013, coinciding with the 320 beginning of the most recent advance period (Fig. 4A), higher velocities (0.4 to $0.8 \pm 0.12 \mathrm{~m}$ 321 day $^{-1}$; 140 to $290 \mathrm{~m} \mathrm{a}^{-1}$ ) had spread over a large area of the glacier tongue (Fig. 4C). Between 322 January and February 2016, velocities at the tongue ranged between 0 and $1.6 \pm 0.10 \mathrm{~m}^{-1}$ $323\left(580 \mathrm{~m} \mathrm{a}^{-1}\right)$ and increased velocities extended throughout most of the glacier tongue and up to 324 a distinct bowl-shaped area $3 \mathrm{~km}$ up-glacier of the terminus (Fig. 4D). This period of increased velocities coincided with rapid terminus advance (Fig. 4A). By November and December 2016 (Fig. 4E), the highest velocities had shifted to the lower section of the tongue, and the upper section had reverted to slow-flow, with velocities of $<0.2 \pm 0.06 \mathrm{~m} \mathrm{day}^{-1}\left(\sim 70 \mathrm{~m} \mathrm{a}^{-1}\right)$. 


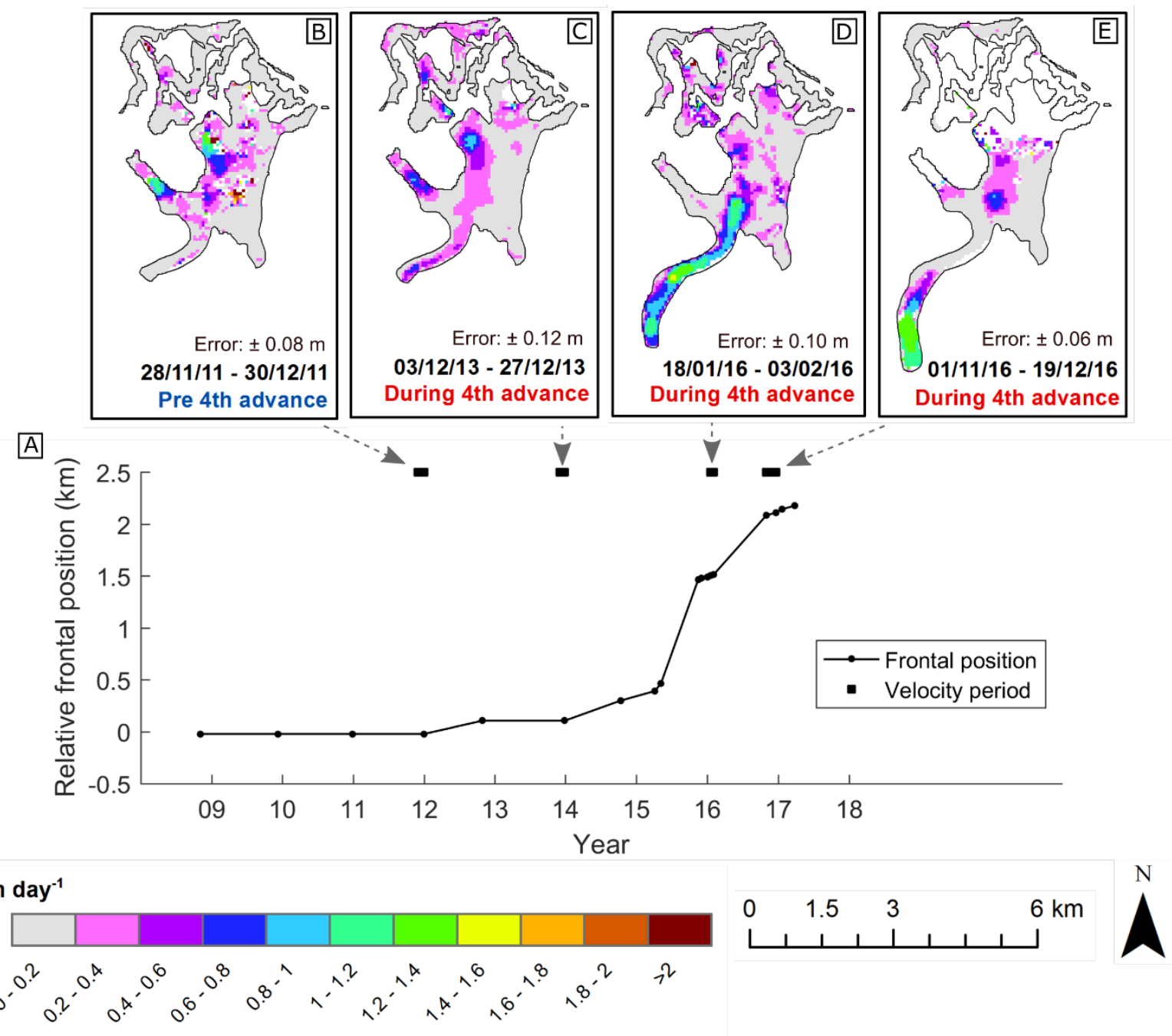

333 Figure 4: Velocities $\left(\mathrm{m} \mathrm{day}^{-1}\right)$ on Sabche Glacier during 2011, 2013 and 2016 (B-E), arranged along

334 a timeline with frontal position changes (A) for the same period. The glacier outlines show changes in

335 the frontal positions of the glacier. The velocities were calculated using $15 \mathrm{~m}$ resolution imagery. elevation gain of up to $90 \pm 6.19 \mathrm{~m} \mathrm{a}^{-1}$ at the glacier terminus and surface lowering of between $10 \pm 6.19$ and $60 \pm 6.19 \mathrm{~m} \mathrm{a}^{-1}, 2-3 \mathrm{~km}$ further up-glacier, with the maximum surface lowering occurring in a distinct bowl-shaped area at the top of the glacier tongue (Fig. 5A). This change in elevation coincided with the advance of the terminus (Fig. 5B and C). The largest surface lowering along the centre line occurred between 1.8 and $4.8 \mathrm{~km}$ from the glacier headwall (Fig. 
$3445 \mathrm{~A}$ and D), and the largest surface elevation gain occurred from $4.8 \mathrm{~km}$ onwards (Fig. 5A and 345 D). Mean glacier elevation change per $200 \mathrm{~m}$ elevation band was positive near the glacier 346 terminus (3600-4200 m elevation), ranging from $22 \pm 6.19 \mathrm{~m} \mathrm{a}^{-1}$ to $54 \pm 6.19 \mathrm{~m} \mathrm{a}^{-1}$ (Fig. 5E). 347 In the intermediate elevation bands, between 4200 and 4800 m elevation, mean elevation 348 change was negative, with a maximum mean surface lowering of $-18 \pm 6.19 \mathrm{~m} \mathrm{a}^{-1}$ (Fig. 5E). 349 The area of maximum elevation loss, between 1.8 and $4.8 \mathrm{~km}$ distance from the headwall had 350 a net volume change of $-2.8 \times 10^{7} \pm 0.1 \times 10^{7} \mathrm{~m}^{3} \mathrm{a}^{-1}$ and the area of maximum elevation gain at 351 the glacier terminus, from $4.8 \mathrm{~km}$ onwards, had a net volume change of $+2.7 \times 10^{7} \pm 0.3 \times 10^{6}$ $352 \mathrm{~m}^{3} \mathrm{a}^{-1}$ (Fig. 5A and D). 


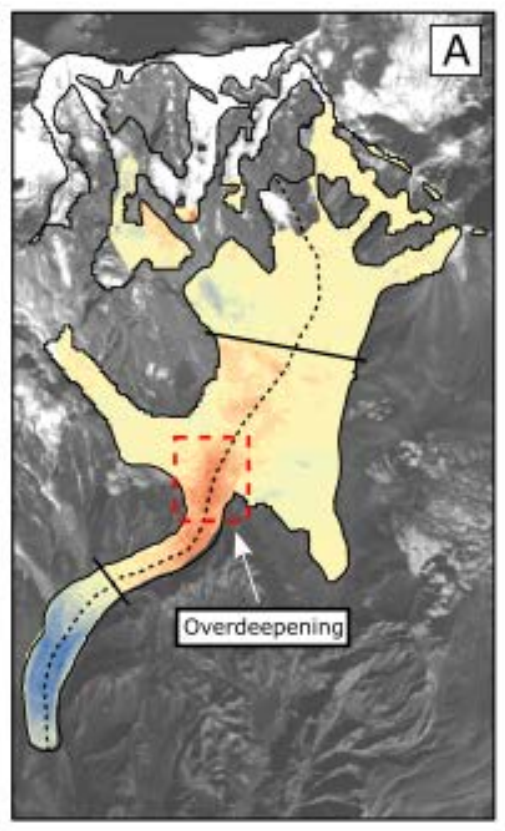

Elevation change $\left(\mathrm{m} \mathrm{a}^{-1}\right)$
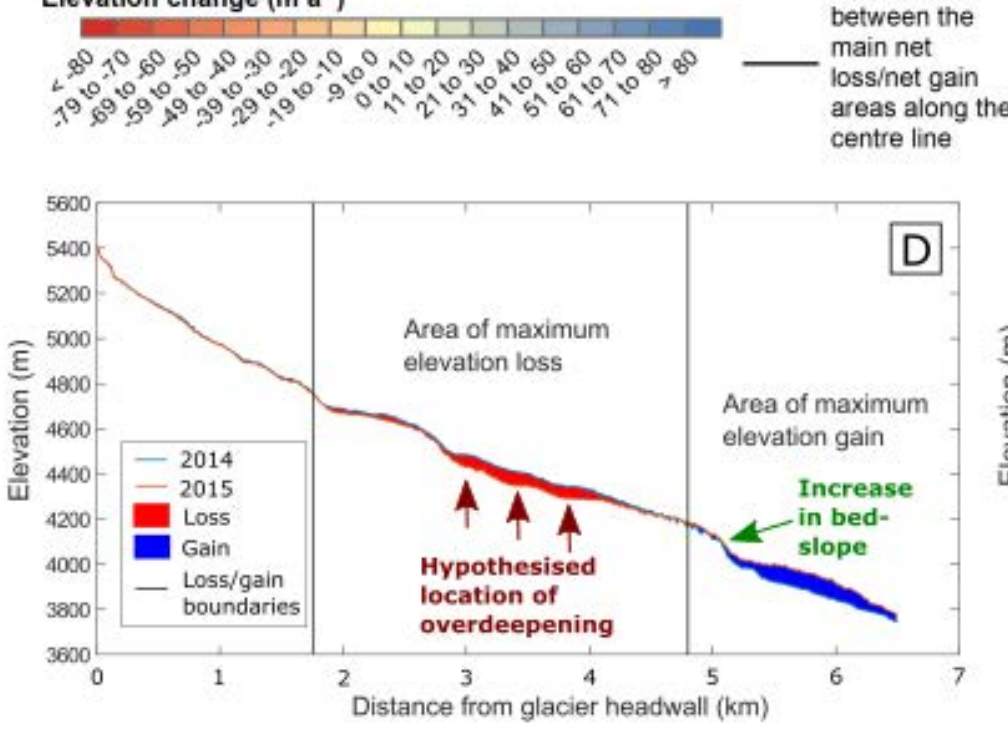
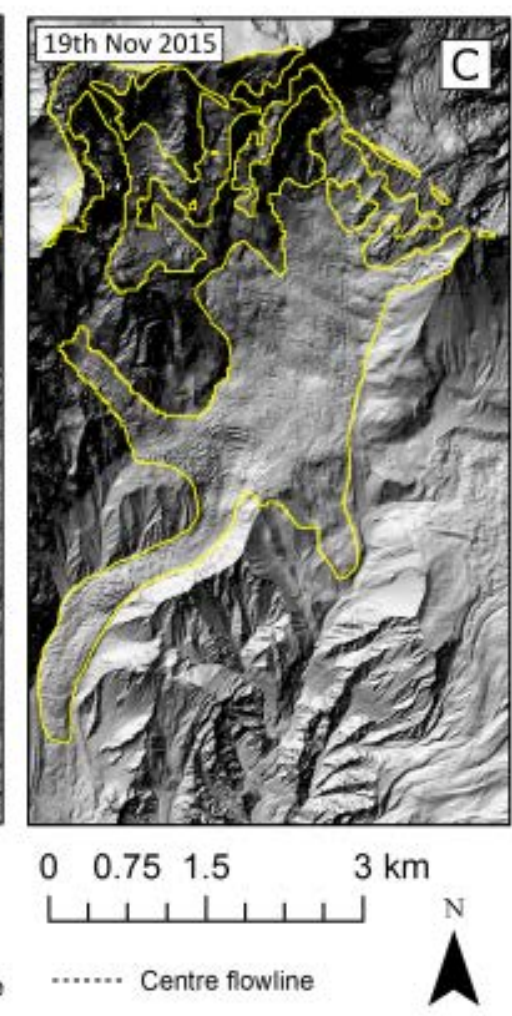

Area $\left(\mathrm{km}^{2}\right)$

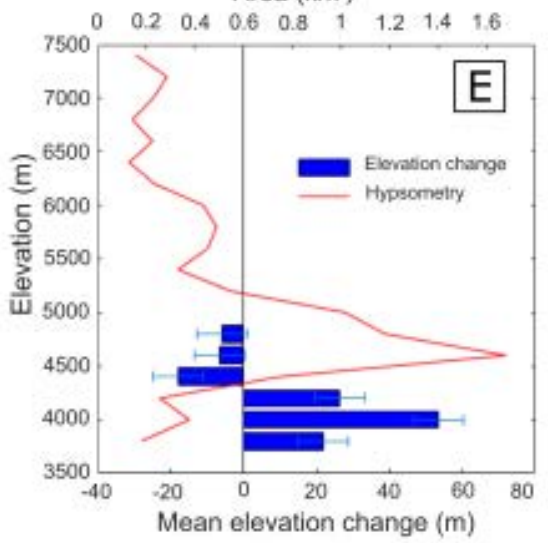

Figure 5: A) Surface elevation change $\left(\mathrm{m} \mathrm{a}^{-1}\right)$ calculated from the $12^{\text {th }}$ October 2014 (towards the beginning of the surge) and $19^{\text {th }}$ November 2015 (middle of the surge) Pléiades DEMs, and the location of the glacier central flowline, the red dashed box indicates the location of the overdeepening B) 2014 DEM hill-shade (beginning of surge), C) 2015 DEM hill-shade (middle of surge) and D) central flowline long profiles of the 2014 and 2015 DEMs revealing surface elevation changes between the two dates, as the surge progressed. Red areas show net elevation loss, blue areas show net elevation gain. The black lines show the boundary between the sections of loss and gain at 1.8 and 4.8 $\mathrm{km}$ distance from the headwall. The large increase in slope in the bed topography at the location where the glacier tongue repeatedly disconnects is indicated with a green arrow. The location of the hypothesised subglacial overdeepening is indicated with a maroon arrow. E) Mean elevation change $\left(\mathrm{m} \mathrm{a}^{-1}\right)$ on Sabche Glacier calculated between $12^{\text {th }}$ October 2014 and $19^{\text {th }}$ November 2015 per $200 \mathrm{~m}$ elevation band and the distribution of glacier area with elevation (red line). 


\subsection{Glacier surface morphology}

370 Changes in the glacier's surface morphology were analysed using the Pléiades DEMs. Between $37112^{\text {th }}$ October 2014 (towards the beginning of the surge) and $19^{\text {th }}$ November 2015 (midway 372 through the surge), several striking morphological changes occurred on the glacier surface (Fig. 373 6). On $12^{\text {th }}$ October 2014, the glacier tongue and west tributary were heavily crevassed, but 374 most of the upper glacier area had a relatively smooth, crevasse-free surface (Fig. 6A). By $19^{\text {th }}$ 375 November 2015, the crevassing had propagated up-glacier to cover most of the glacier surface 376 with large extensional crevasses appearing in the upper glacier area and compressional crevasses occurring at the glacier terminus (Fig. 6B). In 2014, a distinctive lobe-shaped surface feature, approximately 200 m wide and with a smooth surface, was observed just up-glacier of 379 the tongue (Fig. 6A and C). By 2015, this feature had been replaced by a large and heavily crevassed bowl-shaped depression with an area of $\sim 0.3 \mathrm{~km}^{2}$ (Fig. $6 \mathrm{~B}$ and D). This bowl-shaped area is also visible in the same location on the glacier in a CORONA satellite image from $19^{\text {th }}$ November 1970 and comparison of the 1970 image with the 2015 Pléiades scene shows very similar crevasse patterns (Fig. 7B and C). This includes crescentic extensional crevassing on the north-east side and a line of intense crevassing across the narrow valley at the top of the glacier tongue (highlighted in yellow in Fig. 7B and C). 


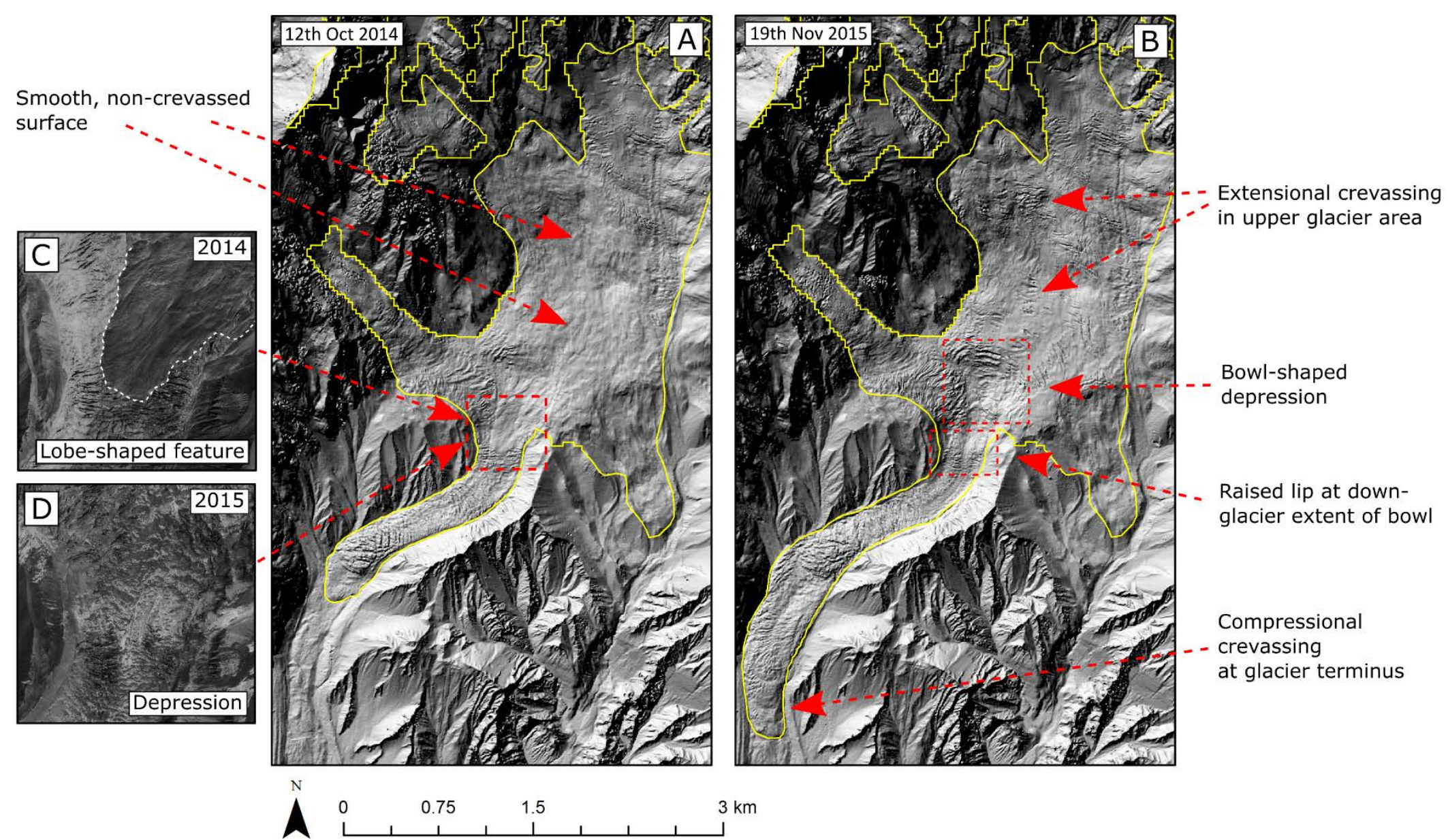

summary of the morphological changes on the surface of Sabche Glacier between A) $12^{\text {th }}$ October 2014 and B) $19^{\text {th }}$ November 2015 (background image: hillshades of Pléiades DEMs). C) Magnified view of the lobe-shaped feature on $12^{\text {th }}$ October 2014 and D) same view on $19^{\text {th }}$ November 2015 with the heavily crevassed depression (background images: Pléiades panchromatic scenes of the same dates). 

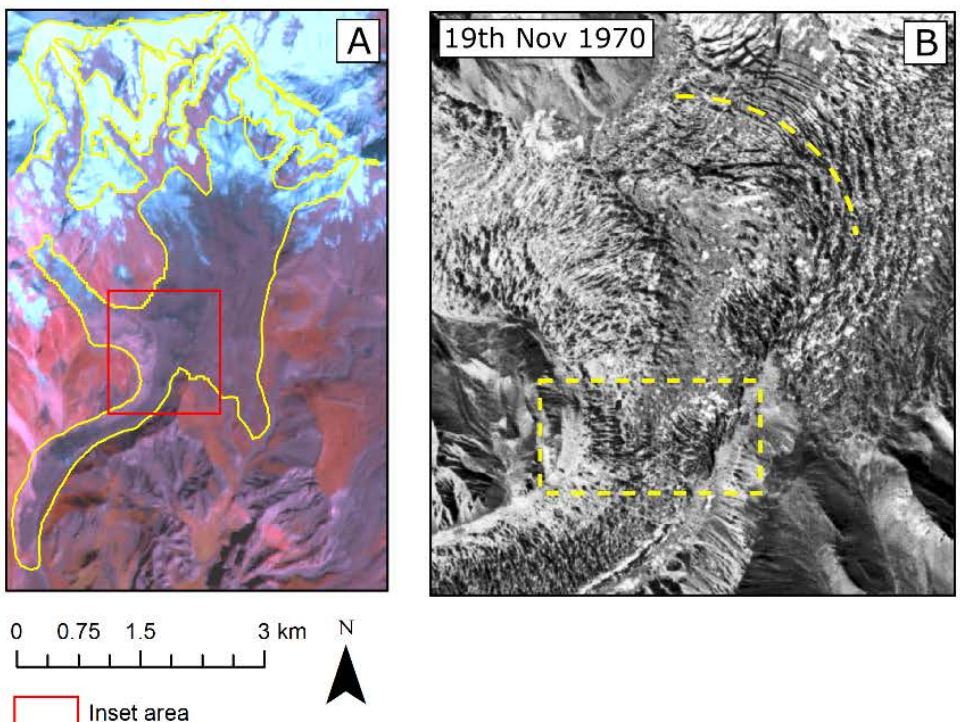

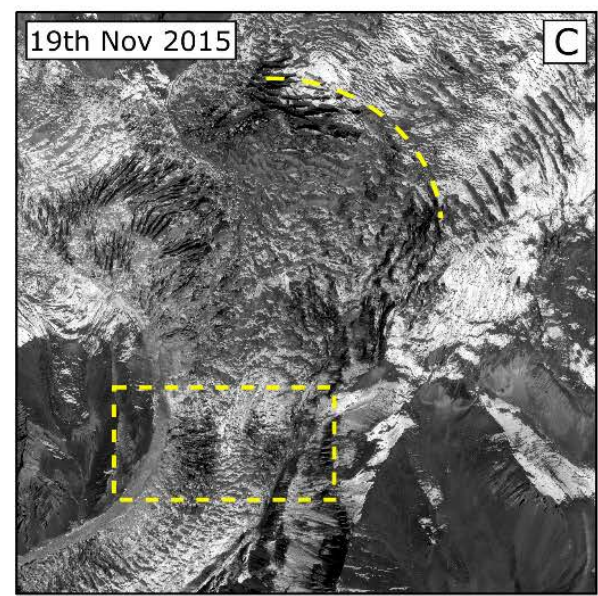

391

392

393

394

395

396

397

398

399

Figure 7: Repeated appearance of a bowl-shaped depression and similar crevasse patterns, $3 \mathrm{~km}$ upglacier of the terminus in 1970 and 2015. (A) Location of bowl-shaped depression, (B) crevasse patterns in a CORONA satellite image from $19^{\text {th }}$ November 1970 and (C) in a Pléiades satellite image from $19^{\text {th }}$ November 2015. The yellow dashed curved lines highlight similar crescentic crevassing and the yellow dashed boxes highlight similar intense crevassing at the point where the glacier flows into the narrow valley. 


\subsection{Sabche Glacier surge characteristics}

402

403

404

405

406

407

408

409

410

411

412

413

414

415

416

417

418

419

420

421

422

423

Several independent lines of evidence strongly suggest that Sabche Glacier is a surge-type glacier. These include: i) regularly fluctuating terminus positions; ii) rapid ice surface velocity acceleration and deceleration; iii) large and rapid surface elevation changes, and; iv) widespread propagation of crevassing on the glacier surface (Grant et al. 2009; Meier and Post 1969; Murray et al. 2003; Sharp 1988). Our data suggest that the glacier surged up to four times during the last 50 years and, from 1991 onwards, surged every 10 to 11 years (Fig. 2). However, a gap in the terminus position change dataset, between 1974 and 1988, may mean an additional surge was missing from the record: based on the 10 to 11-year cycle of the three most recent surges, we would expect another surge to have initiated between 1978 and 1980 . While there has been no previous record of glacier surges in the central Himalayas to our knowledge, this new discovery of a surge-type glacier helps validate a recent model that predicted surges in this region (Sevestre and Benn 2015) and suggests that there might be other undocumented surgetype glaciers in the region.

Based on the terminus position change chronology (from 1991 to 2017) (Fig. 2), Sabche Glacier has one of the shortest surge cycles (10 to 11 years) (Table 1) and quiescence phases (4 to 7 years) ever recorded. For comparison, between 1905 and 1995, the surge cycle of Variegated Glacier in Alaska ranged from 13 to 18 years and between the 1982/3 and 1995 surges, it had a quiescence phase of 12 years (Eisen et al. 2005; Kamb et al. 1985). Shokal'sky Glacier in the Zailai-Alatau mountain range in Kazakhstan has a surge cycle of 11 to 12 years, and Medvezhiy Glacier and North Tanymas Glacier in the Pamirs have surge cycles of 12 to 14 years and 13 years, respectively (Dolgoushin and Osipova 1975). Sabche Glacier could therefore represent an end-member of a spectrum of observed glacier surge cycle lengths 
ranging from slow surge cycles (40 to 130 years) in Svalbard and Arctic Canada (Frappé and

Dowdeswell et al. 1991; Kotlyakov et al. 2008). Therefore, it is important to understand Sabche

Glacier's surging mechanism to capture the full range of surge-type glacier behaviour globally.

Table 1: Summary of the surge and surge cycle lengths, maximum velocity $\left(\mathrm{m} \mathrm{day}^{-1}\right)$ and terminus advance $(\mathrm{km})$ for surge-type glaciers in different regions. Those in Arctic Canada and Svalbard tend have slow surge cycles, while those in the Pamirs, Karakoram, northwest North America and Iceland, tend to have rapid surge cycles. Sources: (Copland et al. 2011; Desio 1954; Dolgoushin and Osipova 1975; Dowdeswell et al. 1991; Frappé and Clarke 2007; Kotlyakov et al. 2008; Murray et al. 2003; Murray et al. 2000).

\begin{tabular}{lcccc}
\hline Glacier region & $\begin{array}{c}\text { Surge duration } \\
(\mathbf{y r})\end{array}$ & $\begin{array}{c}\text { Surge cycle } \\
\text { duration } \\
\text { (yr) }\end{array}$ & $\begin{array}{c}\text { Maximum } \\
\text { Velocity (m/day) }\end{array}$ & $\begin{array}{c}\text { Terminus } \\
\text { advance } \\
\text { (km) }\end{array}$ \\
\hline $\begin{array}{l}\text { Arctic Canada } \\
\text { and Svalbard }\end{array}$ & 3 to 10 & 40 to 130 & 0.1 to 16 & 0 to 3 \\
\hline $\begin{array}{l}\text { Pamirs, } \\
\text { Karakoram, } \\
\text { northwest North }\end{array}$ & 1 to 2 & 11 to 40 & 3 to 110 & 0 to 7.5 \\
$\begin{array}{l}\text { America, Iceland } \\
\text { Sabche Glacier, }\end{array}$ & 3 to 5 & 10 to 11 & & \\
Nepal & & & & 2.2 \\
\hline
\end{tabular}

The short surge cycle length of Sabche Glacier is more common in glacier surges driven by a hydrological trigger such as Variegated Glacier ( 15 years) (Eisen et al. 2005; Kamb 1987), Bering Glacier in Alaska ( 26 years) (Fleisher et al. 1998) and Lowell Glacier in Yukon, 441 Canada ( 15 years) (Bevington and Copland 2014). In contrast, thermally-triggered surge 442 cycles tend to be longer (> 50 years) (Benn et al. 2009; Dowdeswell et al. 1991; Frappé and 443 Clarke 2007). However, Sabche Glacier's surging behaviour reveals some unusual 
characteristics compared to other hydrologically-triggered surge behaviour. First, the length of its surge phases (3 to 5 years) are more typical of the thermally triggered surges of Svalbard (3 to 10 years) (Dowdeswell et al. 1991) than hydrologically-controlled ones (1 to 2 years) (Björnsson 1998; Harrison et al. 1994; Kamb et al. 1985). The quiescent phase (4 to 7 years) is also far shorter than surge-type glaciers controlled by either thermal or hydrological basal conditions (Dowdeswell et al. 1991; Eisen et al. 2005; Meier and Post 1969). These, together with the unusual rapidity of the surge cycle (10-11 years), suggest that other factors might be influencing the cyclicity of the surges.

During the most recent surge, the coincidence of surface lowering (Fig. 5), intense crevassing (Fig. 6B) and increased velocities (Fig. 4D) in a distinct bowl-shaped area $3 \mathrm{~km}$ up-glacier from the terminus, strongly suggests that the ice responsible for terminus advance originated in this relatively localised reservoir mid-way along the glacier central flowline, rather than coming from further up-glacier. This bowl-shaped depression appears in satellite imagery from 1970 and 2015 (both years when the glacier was surging) (Fig. 7), and we hypothesise that its development is related to a subglacial basin, or overdeepening, in the bed topography (Cook and Swift 2012). A slight concavity is visible in the 2015 ice surface long profile in Figure 5D. We also note the raised bump in the surface topographic expression at the down-glacier extent of the bowl in Figure $6 \mathrm{~B}$ and the transverse line of intense extensional crevassing, visible in both 1970 and 2015 (yellow, dashed box in Fig. 7B and C) from which we infer the location of the down-glacier lip, or adverse slope, of a subglacial overdeepening. This leads us to hypothesise that Sabche Glacier's surging behaviour is, in part, controlled by subglacial topography. In particular, we suggest that the narrow valley and adverse slope of the overdeepening provide resistance to glacier flow (Cook and Swift 2012), allowing ice to build up in the overdeepening to a sufficient thickness to cause surging. This leads to a much shorter quiescence phase than for surge-type glaciers controlled solely by thermal or hydrological basal 
conditions. If ice was not trapped in the overdeepening, it might not be able to accumulate enough to surge. No other glacier surges have been observed in the region to date, despite favourable climatic conditions (Sevestre and Benn 2015), so we speculate that the behaviour is specific to Sabche Glacier, i.e. the subglacial topography.

Based on our observations, we propose a conceptual model to explain the potential role of subglacial topography in Sabche Glacier’s surge cyclicity.

1. Quiescent phase: ice accumulates in the overdeepening on the glacier. The downglacier lip of the overdeepening and narrow valley provide resistance to glacier flow further down-valley. Velocities on the glacier tongue are low and there is minimal change in terminus position.

2. Surge phase 1 (rapid advance): sufficient ice accumulates to allow ice to flow out of the overdeepening (Fig. 6C), leading to rapid down-stream ice flow. The narrow and steep subglacial topography facilitates rapid advance and high flow velocities.

3. Surge phase 2 (moderate advance): The ice reservoir in the overdeepening becomes depleted and the surging ice continues down-glacier. Maximum ice velocities propagate down-glacier. Eventually the glacier tongue thins and the lower part disconnects from the upper part and begins to stagnate and down-waste.

A similar topographic mechanism was predicted to influence the slow surge of a small, unnamed glacier in the Yukon region in Canada, monitored between 2006 and 2009 (Flowers et al. 2011). Using an ice flow model, they demonstrated that a bedrock ridge on the downglacier side of an overdeepening on the glacier, could provide added resistance to ice flow. This promoted growth in the overdeepening during quiescence, allowing the glacier to surge, even under negative mass balance conditions. Bedrock also played an important role in glacier surging in the glacier flowline modelling of Budd and McInnis (1974), who showed that steeper 
bedrock profiles led to surges at lower velocities and in thinner glaciers. This suggests that some glacier surges are strongly influenced by subglacial topography, and not solely controlled, or even triggered by, hydrological or thermal basal changes. Given the steep subglacial topography found in many high mountain regions, topographically-influenced surging may be important elsewhere, and potentially produce very rapid and hazardous surges.

A subglacial overdeepening might also preferentially collect unconsolidated sediments (subglacial till) (Cook and Swift 2012), which could have an additional influence on the temporal pattern of surges observed on Sabche Glacier. When water pressure in the till increases sufficiently to support the overlying ice, it can dilate and deform, leading to glacier surging (Turrin et al. 2014). For example, subglacial till deformation has been inferred to generate regular (every $\sim 7$ years between 1973 and 2012) pulses of glacier acceleration observed on Ruth Glacier in Alaska (Turrin et al. 2014). Till failure is also thought to have influenced periodic (every 12 years) accelerations on Black Rapids Glacier in Alaska during its quiescence phase (Nolan 2003). However, subglacial observations (e.g. geophysical data of bed topography and substrate) are required to test this hypothesis for Sabche Glacier, and they do not currently exist.

It is also possible that basal hydrology played a key role in Sabche Glacier's surging behaviour. In particular, meltwater could accumulate in a bowl-shaped depression as the ice thickens, or through seasonal change (Cook and Swift 2012). Moreover, once the glacier thickens sufficiently to overcome the resistance offered by the topography, it is likely to trigger a positive feedback whereby the initial basal sliding across the bedrock promotes frictional/strain heating that generates further meltwater and further increases basal sliding. However, our data are not at a high enough temporal resolution to test whether there is a seasonal influence on the onset and termination of the surges and we cannot analyse changes to meltwater outflow due to limited hydrological data. 
518 While we acknowledge that it is not possible to test our hypothesis of a subglacial topographic 519 control on Sabche Glacier's surge-type behaviour with the current available data, we suggest 520 that future research should prioritise surveying the bed to confirm the presence/absence of a 521 bedrock overdeepening and subglacial till and the configuration of subglacial meltwater 522 drainage.

523 A question still arises as to why, despite occurring at regular (approximately 10 years) intervals, 524 there are marked differences in the size of the two most recent surges on Sabche Glacier? The 525 most recent surge, from 2012 onwards, advanced twice the distance of the previous surge at 526 the last measured date $\left(25^{\text {th }}\right.$ March 2017) (Fig. 2). This suggests that the size of the surge is not 527 necessarily related to surge-cycle length. A possible explanation is that a larger proportion of 528 the glacier overcame resistance and became involved in the surge. Additional data, such as 529 accumulation rates, subglacial topography and surface elevation change covering the three 530 most recent surges would be required to test this hypothesis. 


\section{Conclusions}

534 In this paper, we report a newly-discovered surge-type glacier, the presence of which is 535 consistent with previous work predicting the occurrence of surge-type glaciers in the central 536 Himalayas (Sevestre and Benn 2015). Using a combination of manual digitisation, feature 537 tracking and DEM differencing, we mapped changes in the terminus position, velocity and 538 surface elevation of Sabche Glacier from 1967 to 2017. Our results show that Sabche Glacier 539 surged four times in the last 50 years. The three most recent surges occurred at 10 to 11 -year 540 cycles, making it one of the shortest surge-cycles ever recorded. Its unusual surge-type 541 characteristics (very short surge cycle, but relatively long surge phase of 3 to 5 years), do not 542 fit clearly with the established paradigms for hydrologically- or thermally-driven surge 543 mechanisms. Rather, the persistent reappearance of a bowl-shaped depression above a narrow 544 valley constriction lead us to suggest that Sabche Glacier's surge-type behaviour is influenced by subglacial topography. Specifically, we propose that the configuration of bedrock above the glacier tongue promotes the accumulation of mass in the overdeepening and leads to a more rapid surge cycle than would otherwise be possible. On this basis, our data highlight the importance of topography in controlling surge-type glacier behaviour, which may be relevant to glacier surging in other mountainous regions.

\section{Acknowledgements}

552 We thank the editor and three anonymous reviewers for their constructive comments which

553 have improved the paper. This work was funded by the IAPETUS Natural Environment

554 Research Council Doctoral Training Partnership. Grant code: NE/LOO2590/1. The Pléiades 555 stereo satellite images were provided by ESA and the Landsat and CORONA satellite images 
557 the Pléiades DEMs.

558 
Benn, D.I., Kristensen, L., \& Gulley, J.D. (2009). Surge propagation constrained by a persistent subglacial conduit, Bakaninbreen-Paulabreen, Svalbard. Annals of Glaciology, 50, 81-86 Berthier, E., Vincent, C., Magnússon, E., Gunnlaugsson, Á.P., Pitte, P., Le Meur, E., Masiokas, M., Ruiz, L., Pálsson, F., Belart, J.M.C., \& Wagnon, P. (2014). Glacier topography and elevation changes derived from Pléiades sub-meter stereo images. The Cryosphere, 8, 2275-2291

Bevington, A., \& Copland, L. (2014). Characteristics of the last five surges of Lowell Glacier, Yukon, Canada, since 1948. Journal of Glaciology, 60, 113-123

Björnsson, H. (1998). Hydrological characteristics of the drainage system beneath a surgng glacier. Nature, 395, 771-774

Budd, W.F., \& McInnis, B.J. (1974). Modelling periodically surging glaciers. Science, 186, 925-927

Burke, M.J., Woodward, J., Russell, A.J., Fleisher, P.J., \& Bailey, P.K. (2010). The sedimentary architecture of outburst flood eskers: A comparison of ground-penetrating radar data from Bering Glacier, Alaska and Skeithararjokull, Iceland. Geological Society of America Bulletin, 122, 1637-1645 Clarke, G.K.C. (1987). Fast glacier flow: Ice streams, surging, and tidewater glaciers. Journal of Geophysical Research, 92, 8835

Clarke, G.K.C., Collins, S.G., \& Thompson, D.E. (1984). Flow, thermal structure, and subglacial conditions of a surge-type glacier. Canadian Journal of Earth Sciences, 21, 232-240

Cook, S.J., \& Swift, D.A. (2012). Subglacial basins: Their origin and importance in glacial systems and landscapes. Earth-Science Reviews, 115, 332-372

Copland, L., Pope, S., Bishop, M.P., Shroder, J.F., Clendon, P., Bush, A., Kamp, U., Seong, Y.B., \& Owen, L.A. (2009). Glacier velocities across the central Karakoram. Annals of Glaciology, 50, 41-49

Copland, L., Sylvestre, T., Bishop, M.P., Shroder, J.F., Seong, Y.B., Owen, L.A., Bush, A., \& Kamp, U. (2011). Expanded and Recently Increased Glacier Surging in the Karakoram. Arctic, Antarctic, and Alpine Research, 43, 503-516

Desio, A. (1954). An Exceptional Glacier Advance in the Karakoram-Ladakh Region. Journal of Glaciology, 2, 383-385

Dolgoushin, L.D., \& Osipova, G.B. (1975). Glacier surges and the problem of their forecasting. IAHS publication, 104 (Symposium at Moscow 1971 - Snow and Ice), 292-304

Dowdeswell, J.A., Hamilton, G., \& Hagen, J.O. (1991). The duration of the active phase on surge-type glaciers: contrasts between Svalbard and other regions. Journal of Glaciology, 37, 388-400

Eisen, O., Harrison, W.D., Raymond, C.F., Echelmeyer, K.A., Bender, G.A., \& Gorda, J.L.D. (2005). Variegated Glacier, Alaska, USA: a century of surges. Journal of Glaciology, 51, 399-406

Evans, S.G., \& Delaney, K.B. (2015). Catastrophic Mass Flows in the Mountain Glacial Environment. In W. Haeberli, C. Whiteman, \& J.F. Shroder Jr (Eds.), Snow and Ice-Related Hazards, Risks, and Disasters. (pp. 563-606). Amsterdam: Elsevier

Fleisher, P.J., Cadwell, D.H., \& Muller, E.H. (1998). Tsivat basin onduit system persists through two surges, Bering Piedmont Glacier, Alaska. GSA Bulletin, 110, 877-887

Flowers, G.E., Roux, N., Pimentel, S., \& Schoof, C.G. (2011). Present dynamics and future prognosis of a slowly surging glacier. The Cryosphere, 5, 299-313

Fort, M. (1987). Sporadic morphogenesis in a continental subduction setting: an example from the Annapurna range, Nepal Himalaya. Zeitschrift für Geomorphologie, Supplementary Issues, 9-36 Frappé, T.-P., \& Clarke, G.K.C. (2007). Slow surge of Trapridge Glacier, Yukon Territory, Canada. Journal of Geophysical Research, 112

Gardelle, J., Berthier, E., \& Arnaud, Y. (2012). Slight mass gain of Karakoram glaciers in the early twenty-first century. Nature Geoscience, 5, 322-325

Gardelle, J., Berthier, E., Arnaud, Y., \& Kääb, A. (2013). Region-wide glacier mass balances over the Pamir-Karakoram-Himalaya during 1999-2011. The Cryosphere, 7, 1263-1286

Gardner, J.S., \& Hewitt, K. (1990). A surge of Bualtar Glacier, Karakoram range, Pakistan: a possible landslide trigger. Journal of Glaciology, 36, 159-162

Grant, K.L., Stokes, C.R., \& Evans, I.S. (2009). Identification and characteristics of surge-type glaciers on Novaya Zemlya, Russia Arctic. Journal of Glaciology, 55, 960-971 
Haeberli, W., Kääb, A., Paul, F., Chiarle, M., Mortara, G., Mazza, A., Deline, P., \& Richardson, S. (2002). A surge-type movement at Ghiacciaio del Belvedere and a developing slope instability in the east face of Monte Rosa, Macugnaga, Italian Alps. Norsk Geografisk Tidsskrift - Norwegian Journal of Geography, 56, 104-111

Harrison, W.D., Echelmeyer, K.A., Chacho, E.F., Raymond, C.F., \& Benedict, R.J. (1994). The 198788 surge of West Fork Glacier, Susitna Basin, Alaska, U.S.A. Journal of Glaciology, 40, 241-254

Hewitt, K. (2007). Tributary glacier surges: an exceptional concentration at Panmah Glacier, Karakoram Himalaya. Journal of Glaciology, 53, 181-188

Jiskoot, H., Boyle, P., \& Murray, T. (1998). The incidence of glacier surging in Svalbard: evidence from multivariate statistics. Computers \& Geosciences, 24, 387-399

Kääb, A., Berthier, E., Nuth, C., Gardelle, J., \& Arnaud, Y. (2012). Contrasting patterns of early twentyfirst-century glacier mass change in the Himalayas. Nature, 488, 495-498

Kääb, A., Reynolds, J.M., \& Haeberli, W. (2005). Glacier and Permafrost Hazards in High Mountains, 23, 225-234

Kamb, B. (1987). Glacier surge mechanism based on linked cavity configuration of the basal water conduit system. Journal of Geophysical Research, 92, 9083

Kamb, B., Raymond, C.F., Harrison, W.D., Engelhart, H., Echelmeyer, K.A., Humphrey, N., Brugman, M.M., \& Pfeffer, T. (1985). Glacier surge mechanism: 1982-1983 surge of Variegated Glacier, Alaska. Science, 227, 469-479

King, O., Quincey, D.J., Carrivick, J.L., \& Rowan, A.V. (2017). Spatial variability in mass loss of glaciers in the Everest region, central Himalayas, between 2000 and 2015. The Cryosphere, 11, 407426

Kotlyakov, V.M., Osipova, G.B., \& Tsvetkov, D.G. (2008). Monitoring glacier surges of the Pamirs, central Asia, from space. Annals of Glaciology, 48, 125-134

Lea, J.M., Mair, D.W.F., \& Rea, B.R. (2014). Evaluation of existing and new methods of tracking glacier terminus change. Journal of Glaciology, 60, 323-332

Leprince, S., Barbot, S., Ayoub, F., \& Avouac, J.-P. (2007). Automatic and Precise Orthorectification, Coregistration, and Subpixel Correlation of Satellite Images, Application to Ground Deformation Measurements. IEEE Transactions on Geoscience and Remote Sensing, 45, 1529-1558

Meier, M.F., \& Post, A. (1969). What are glacier surges? Canadian Journal of Earth Sciences, 6, 807817

Moon, T., \& Joughin, I. (2008). Changes in ice front position on Greenland's outlet glaciers from 1992 to 2007. Journal of Geophysical Research, 113

Murray, T., Dowdeswell, J.A., Drewry, D.J., \& Frearson, I. (1998). Geometric evolution and ice dynamics during a surge of Bakaninbreen, Svalbard. Journal of Glaciology, 44, 263-272

Murray, T., Strozzi, T., Luckman, A., Jiskoot, H., \& Christakos, P. (2003). Is there a single surge mechanism? Contrasts in dynamics between glacier surges in Svalbard and other regions. Journal of Geophysical Research: Solid Earth, 108

Murray, T., Stuart, G.W., Miller, P.J., Woodward, J., Smith, A.M., Porter, P.R., \& Jiskoot, H. (2000). Glacier surge propagation by thermal evolution at the bed. Journal of Geophysical Research: Solid Earth, 105, 13491-13507

Nolan, M. (2003). The “Galloping Glacier” trots: decadal-scale speed oscillations within the quiescent phase. Annals of Glaciology, 36, 7-13

Nuth, C., \& Kääb, A. (2011). Co-registration and bias corrections of satellite elevation data sets for quantifying glacier thickness change. The Cryosphere, 5, 271-290

Oi, H., Higaki, D., Yagi, H., Usuki, N., \& Yoshino, K. (2014). Report of the investigation of the flood disaster that occurred on May 5, 2012 along the Seti River in Nepal. International Journal of Erosion Control Engineering, 7, 111-117

Pieczonka, T., \& Bolch, T. (2015). Region-wide glacier mass budgets and area changes for the Central Tien Shan between 1975 and 1999 using Hexagon KH-9 imagery. Global and Planetary Change, 128, $1-13$

Quincey, D.J., Braun, M., Glasser, N.F., Bishop, M.P., Hewitt, K., \& Luckman, A. (2011). Karakoram glacier surge dynamics. Geophysical Research Letters, 38, L18504

Richardson, S.D., \& Reynolds, J.M. (2000). An overview of glacial hazards in the Himalayas. Quaternary International, 65-66, 31-47 
Scherler, D., Leprince, S., \& Strecker, M. (2008). Glacier-surface velocities in alpine terrain from optical satellite imagery-Accuracy improvement and quality assessment. Remote Sensing of 668 Environment, 112, 3806-3819

669 Schwanghart, W., Bernhardt, A., Stolle, A., Hoelzmann, P., Adhikari, B.R., Andermann, C., Tofelde, 670 S., Merchel, S., Rugel, G., Fort, M., \& Korup, O. (2015). Repeated catastrophic valley infill following medieval earthquakes in the Nepal Himalaya. Sciencexpress, 1-9

672 Sevestre, H., \& Benn, D.I. (2015). Climatic and geometric controls on the global distribution of surgetype glaciers: implications for a unifying model of surging. Journal of Glaciology, 61, 646-662

674 Sharp, M.J. (1988). Surging glaciers: behaviour and mechanisms. Progress in Physical Geography, 12, $675 \quad 349-370$

676 Turrin, J.B., Forster, R.R., Sauber, J.M., Hall, D.K., \& Bruhn, R.L. (2014). Effects of bedrock lithology 677 and subglacial till on the motion of Ruth Glacier, Alaska, deduced from five pulses from 1973 to 2012. 678 Journal of Glaciology, 60, 771-781

679 Yamanaka, H. (1982). Radiocarbon ages of upper quaternary deposit in central Nepal and their 680 geomorphological significance. The Science Reports of Tohoku University, 7th series (Geography), 32, 46-60 
685 Figure 1: Study area map. A) Location of the central Himalayas and the A-M region in Nepal, B) 686 location of Sabche Glacier in the A-M region, Pokhara and Ghachowk hydrological station and C) map of Sabche Glacier with the central flowline (yellow dotted line), the approximate position of the recurring separation point between the main body of the glacier and its tongue (red line) and the location of Annapurna III. The white arrow indicates the location of the glacier terminus. The base image is a pan-sharpened Landsat 8 scene from $1^{\text {st }}$ December 2015, courtesy of USGS.

Figure 2: Glacier frontal position changes of Sabche Glacier relative to 1967 with individual advance (surge) periods numbered (1 to 4). Circles plot measurement dates.

693 Figure 3: A large increase in slope encouraging localised acceleration and extension, leading to the 694 separation of Sabche Glacier's tongue from the main part of the glacier and the exposure of bedrock in November 2017. See Figure 1 for the position of the recurring separation point on Sabche Glacier. Background image: Digital Globe imagery on Google Earth on 10 $0^{\text {th }}$ November 2017.

697 Figure 4: Velocities (m day ${ }^{-1}$ ) on Sabche Glacier during 2011, 2013 and 2016 (B-E), arranged along 698 a timeline with frontal position changes (A) for the same period. The glacier outlines show changes in 699 the frontal positions of the glacier. The velocities were calculated using $15 \mathrm{~m}$ resolution imagery.

700 Figure 5: A) Surface elevation change $\left(\mathrm{m} \mathrm{a}^{-1}\right)$ calculated from the $12^{\text {th }}$ October 2014 (towards the beginning of the surge) and $19^{\text {th }}$ November 2015 (middle of the surge) Pléiades DEMs, and the location of the glacier central flowline, the red dashed box indicates the location of the overdeepening B) 2014 DEM hill-shade (beginning of surge), C) 2015 DEM hill-shade (middle of surge) and D) central flowline long profiles of the 2014 and 2015 DEMs revealing surface elevation changes between the two dates, as the surge progressed. Red areas show net elevation loss, blue areas show net elevation gain. The black lines show the boundary between the sections of loss and gain at 1.8 and 4.8 $\mathrm{km}$ distance from the headwall. The large increase in slope in the bed topography at the location where the glacier tongue repeatedly disconnects is indicated with a green arrow. The location of the hypothesised subglacial overdeepening is indicated with a maroon arrow. E) Mean elevation change $\left(\mathrm{m} \mathrm{a}^{-1}\right)$ on Sabche Glacier calculated between $12^{\text {th }}$ October 2014 and $19^{\text {th }}$ November 2015 per $200 \mathrm{~m}$ elevation band and the distribution of glacier area with elevation (red line).

Figure 6: A summary of the morphological changes on the surface of Sabche Glacier between A) $12^{\text {th }}$ October 2014 and B) 19 ${ }^{\text {th }}$ November 2015 (background image: hill-shades of Pléiades DEMs). C) Magnified view of the lobe-shaped feature on $12^{\text {th }}$ October 2014 and D) same view on $19^{\text {th }}$ November 2015 with the heavily crevassed depression (background images: Pléiades panchromatic scenes of the same dates).

717 Figure 7: Repeated appearance of a bowl-shaped depression and similar crevasse patterns, $3 \mathrm{~km}$ upglacier of the terminus in 1970 and 2015. (A) Location of bowl-shaped depression, (B) crevasse patterns in a CORONA satellite image from $19^{\text {th }}$ November 1970 and (C) in a Pléiades satellite image from $19^{\text {th }}$ November 2015. The yellow dashed curved lines highlight similar crescentic crevassing and the yellow dashed boxes highlight similar intense crevassing at the point where the glacier flows into the narrow valley. 